\title{
Article \\ Inhibitors of Nucleotide Excision Repair Decrease UVB-Induced Mutagenesis-An In Vitro Study
}

\author{
Eszter Fidrus ${ }^{1,2}{ }^{\mathbb{D}}$, Csaba Hegedús ${ }^{1,2}$, Eszter Anna Janka ${ }^{1}$, György Paragh ${ }^{3,4}$, Gabriella Emri $^{1}$ and \\ Éva Remenyik 1,*
}

check for updates

Citation: Fidrus, E.; Hegedûs, C.; Janka, E.A.; Paragh, G.; Emri, G.; Remenyik, É. Inhibitors of Nucleotide Excision Repair Decrease UVB-Induced Mutagenesis-An In Vitro Study. Int. J Mol. Sci. 2021, 22, 1638. https:// doi.org/10.3390/ijms22041638

Academic Editors: Konstantin Volcho, Olga Lavrik and Ennio Prosperi

Received: 8 December 2020

Accepted: 2 February 2021

Published: 6 February 202

Publisher's Note: MDPI stays neutral with regard to jurisdictional claims in published maps and institutional affiliations.

Copyright: (C) 2021 by the authors Licensee MDPI, Basel, Switzerland. This article is an open access article distributed under the terms and conditions of the Creative Commons Attribution (CC BY) license (https:// creativecommons.org/licenses/by/ $4.0 /)$
1 Department of Dermatology, Faculty of Medicine, University of Debrecen, 98 Nagyerdei Krt, 4032 Debrecen, Hungary; fidrus.eszter@med.unideb.hu (E.F.); hegeduscsaba88@gmail.com (C.H.); janka.eszter.a@gmail.com (E.A.J.); gemri@med.unideb.hu (G.E.)

2 Doctoral School of Health Sciences, University of Debrecen, 4032 Debrecen, Hungary

3 Department of Dermatology, Roswell Park Comprehensive Cancer Center, 665 Elm St, Buffalo, NY 14203, USA; gyorgy.paragh@roswellpark.org

4 Department of Cell Stress Biology, Roswell Park Comprehensive Cancer Center, 665 Elm St, Buffalo, NY 14203, USA

* Correspondence: remenyik@med.unideb.hu; Tel.: +36-52-412-345

\begin{abstract}
The high incidence of skin cancers in the Caucasian population is primarily due to the accumulation of DNA damage in epidermal cells induced by chronic ultraviolet B (UVB) exposure. UVB-induced DNA photolesions, including cyclobutane-pyrimidine dimers (CPDs), promote mutations in skin cancer driver genes. In humans, CPDs are repaired by nucleotide excision repair (NER). Several commonly used and investigational medications negatively influence NER in experimental systems. Despite these molecules' ability to decrease NER activity in vitro, the role of these drugs in enhancing skin cancer risk is unclear. In this study, we investigated four molecules (veliparib, resveratrol, spironolactone, and arsenic trioxide) with well-known NER-inhibitory potential in vitro, using UVB-irradiated $\mathrm{CHO}$ epithelial and $\mathrm{HaCaT}$ immortalized keratinocyte cell lines. Relative CPD levels, hypoxanthine phosphoribosyltransferase gene mutation frequency, cell viability, cell cycle progression, and protein expression were assessed. All four molecules significantly elevated $\mathrm{CPD}$ levels in the genome $24 \mathrm{~h}$ after UVB irradiation. However, veliparib, spironolactone, and arsenic trioxide reduced the mutagenic potential of UVB, while resveratrol did not alter UVB-induced mutation formation. UVB-induced apoptosis was enhanced by spironolactone and arsenic-trioxide treatment, while veliparib caused significantly prolonged cell cycle arrest and increased autophagy. Spironolactone also enhanced the phosphorylation level of mammalian target of rapamycin (mTOR), while arsenic trioxide modified UVB-driven mitochondrial fission. Resveratrol induced only mild changes in the cellular UVB response. Our results show that chemically inhibited NER does not result in increased mutagenic effects. Furthermore, the UVB-induced mutagenic potential can be paradoxically mitigated by NER-inhibitor molecules. We identified molecular changes in the cellular UVB response after NER-inhibitor treatment, which may compensate for the mitigated DNA repair. Our findings show that metabolic cellular response pathways are essential to consider in evaluating the skin cancer risk-modifying effects of pharmacological compounds.
\end{abstract}

Keywords: UVB radiation; UVB mutagenesis; nucleotide excision repair (NER); cyclobutane-pyrimidine dimer (CPD) photolesion; veliparib; resveratrol; arsenic trioxide; spironolactone

\section{Introduction}

The incidence of melanoma [1-4] and nonmelanoma skin cancers [4,5] is increasing in lighter skin types and is attributed to enhanced exposure of the skin to ultravioletB (UVB) [6-8]. UVB radiation induces DNA damage in epidermal cells [9]. The most common UVB-induced DNA changes are pyrimidine-pyrimidone photoproducts (6-4PPs) and cyclobutane-pyrimidine dimers (CPDs) $[9,10]$. These photolesions disrupt DNA 
structure by forming stable bonds between two adjacent pyrimidine bases $[10,11]$. CPDs form up to five times more frequently after UVB radiation than 6-4PPs [12,13], and CPDs are the leading cause of UV-signature mutations, specific markers for UV-induced DNA damage [11]. Wei et al. showed that CPDs show different accumulation throughout the genome, as enrichment of UV-signature mutations on specific genetic locations (mutational hotspots) can be detected [14,15].

In human cells, UVB-induced photolesions are repaired by nucleotide excision repair (NER) [16]. NER is highly effective in the repair of 6-4PPs, but less effective in repairing CPDs. Nakagawa et al. showed that $6 \mathrm{~h}$ after UVB irradiation, 6-4PPs are completely removed [17], while more than $40 \%$ of UVB-induced CPDs are left unrepaired even $24 \mathrm{~h}$ after UVB injury [17]. Furthermore, mutation data from epidermal cancer suggest that UVBinduced molecular changes are mainly attributed to CPDs $[9,10,18]$. Defects in the repair process cause rare genetic disorders, including xeroderma pigmentosum (XP), Cockayne syndrome (CS), and trichothiodystrophy (TTH). Patients with these diseases are extremely sensitive to sunlight and, in the case of $\mathrm{XP}$, the risk of skin cancer at an early age is very high [19].

NER function can be both positively and negatively influenced by various chemical agents. Nicotinamide [20,21] and some plant derivatives [22-25] were shown to enhance NER activity in vitro. However, some chemical agents impair DNA repair [26-32], raising the possibility of enhanced skin cancer risk in exposed individuals. Among the repairinhibiting drugs, veliparib, an inhibitor of poly [ADP-ribose] polymerase 1 (PARP1), is currently in clinical trials to target different malignancies [33-36]. Spironolactone $[37,38]$ and arsenic trioxide [39-41] are used in clinical practice for their diuretic and chemotherapeutic properties, respectively. Resveratrol, a natural phytophenol, is a promising compound in UV protection via its anti-inflammatory [42-45], anti-oxidant [45,46], and anticarcinogenic [47-49] effects. Although these chemicals are widely used, there are no in vivo data examining the risk of UVB-induced tumorigenesis in treated individuals or the role of NER inhibition in this risk. NER functionality may have no linear and obligate relationship with UVB-driven mutagenesis; other factors may also influence photocarcinogenesis.

In this study, we aimed to investigate the mutagenic effects of four chemical agentsveliparib, resveratrol, spironolactone, and arsenic trioxide-with known in vitro NERinhibitory properties $[26,29,31,50]$. Since the ability of these molecules to impair NER function is well proven, our aim was to assess whether decreased repair function and increased CPD accumulation by the treatment of the tested chemicals lead to enhanced mutagenesis of epithelial cells in vitro. In addition to their impact on CPD formation and UV-induced mutation burden, we identified other molecular pathways (apoptosis, cell cycle progression, or autophagy) modified by these molecules, which have significant role in cellular UVB response.

\section{Results}

\subsection{All Tested Chemicals Enhance CPD Formation after UVB Irradiation}

To verify the NER-inhibitory effect of veliparib, resveratrol, arsenic trioxide, and spironolactone, $\mathrm{CHO}$ cells were pretreated with the chemicals and irradiated with $20 \mathrm{~mJ} / \mathrm{cm}^{2} \mathrm{UVB}$. In our previous study, we evaluated the kinetics of CPD removal after UVB irradiation, and we found that most of the UV-induced lesions $(\sim 60 \%)$ are eliminated from the DNA in the first $24 \mathrm{~h}$ [51]. According to this and other studies aiming to assess repair efficacy [17,52], we chose to measure the relative CPD content of the cells $24 \mathrm{~h}$ after UVB.

Twenty-four hours post-UVB, a large number of CPDs remained in the cellular DNA reflecting the slow repair of CPD lesions by NER [17]. The relative amount of CPDs was significantly higher in the treated groups compared to that in the nontreated counterparts. In many cases, the number of CPD lesions showed more than a $50 \%$ increase, e.g., the detectable CPD amount was $88 \%$ higher after $4 \mu \mathrm{g} / \mathrm{mL}$ arsenic-trioxide treatment compared with that in the sham-treated group (Figure 1). These findings are consistent with other studies showing that these molecules impair the removal of CPDs $[26,28,29,31,32,50]$. To 
validate these data, we repeated the experiments in $\mathrm{HaCaT}$ human keratinocyte cell line using the most effective concentrations. In our previous study, we have already presented that veliparib treatment reduces CPD repair in this cell line [29], and we also found similar results by resveratrol, spironolactone, and arsenic-trioxide treatment, too (Figure S1).

A

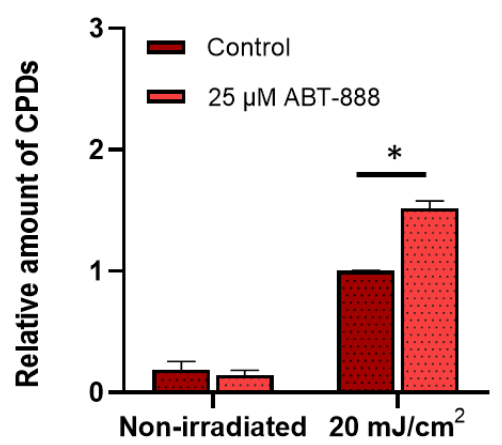

C

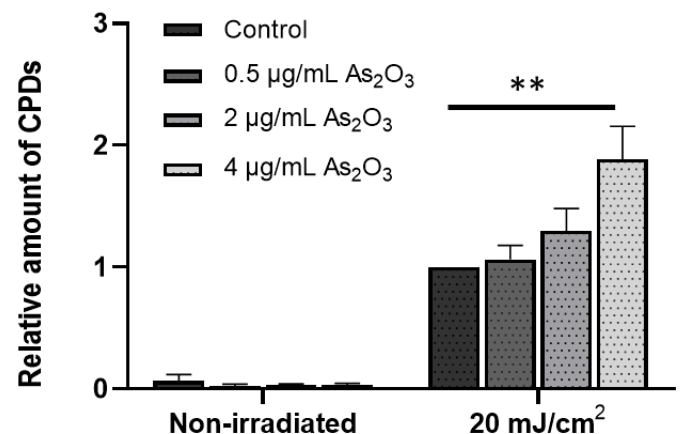

B

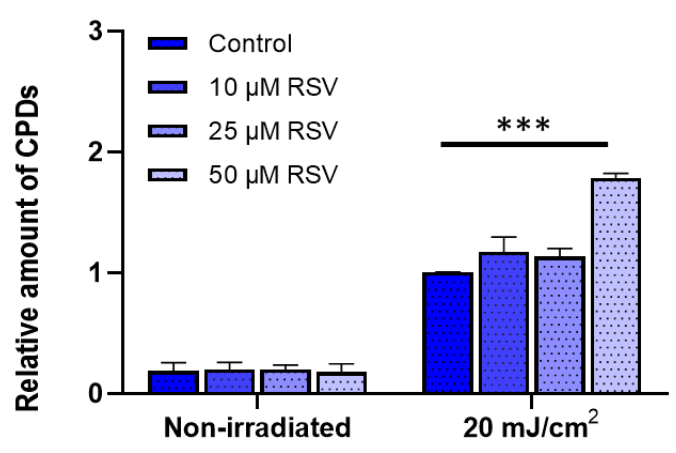

D

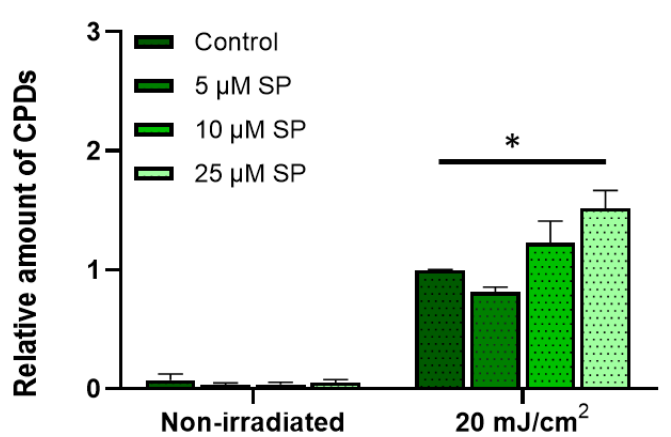

Figure 1. Relative number of cyclobutane-pyrimidine dimer (CPD) photolesions after ultraviolet $\mathrm{B}$ (UVB) irradiation. $\mathrm{CHO}$ cells were pretreated with (A) veliparib (ABT-888), (B) resveratrol (RSV), (C) arsenic trioxide $\left(\mathrm{As}_{2} \mathrm{O}_{3}\right)$, or (D) spironolactone (SP), and then irradiated with $20 \mathrm{~mJ} / \mathrm{cm}^{2}$ UVB. CPD lesions were detected by CPD-specific ELISA $24 \mathrm{~h}$ after the irradiation. CPD amounts were normalized to UVB-irradiated vehicle controls. We present the mean \pm SEM of at least three independent experiments. ${ }^{*}{ }^{* *}$, and ${ }^{* *}$ indicate statistically significant difference at $p<0.05, p<0.01$, and $p<0.001$.

\subsection{CPD Accumulation and UVB-Induced Mutagenesis Show a Nonlinear Relationship}

To evaluate the mutagenic effect of UVB radiation, HPRT gene mutation assays were performed [53]. This assay detects cells carrying heritable mutations in the HPRT gene. First, we assessed the dose dependence of CPD accumulation. Our results show that CPD levels, detected $24 \mathrm{~h}$ after UVB irradiation, increased linearly with the UVB dose (Figure 2A) [54]. Interestingly, UVB-induced mutagenesis did not exhibit a linear dose-response relationship with CPD accumulation. UVB-induced HPRT mutation frequency increased from 0 to $10 \mathrm{~mJ} / \mathrm{cm}^{2} \mathrm{UVB}$, then the mutational rate dropped at $15 \mathrm{~mJ} / \mathrm{cm}^{2}$ (Figure $2 \mathrm{~B}$ ), suggesting that UVB doses with lower cytotoxic effects are more mutagenic [55]. Based on this observation, we chose $10 \mathrm{~mJ} / \mathrm{cm}^{2}$ UVB in our experimental system for HPRT mutation detection. Figure S2 presents the linear reduction of viability after increasing UVB doses.

\subsection{Veliparib, Arsenic-Trioxide, and Spironolactone Treatments Prevent UVB-Induced Mutagenesis}

To assess the effects of chemically induced NER inhibition on UVB mutagenesis (Figure 3), we examined whether the compounds increased the mutation frequency of the HPRT gene after UVB irradiation. Since $\mathrm{HaCaT}$ cells were extremely intolerant to 6-thioguanine (6-TG) selection medium and formed a very low number of colonies after UVB radiation, HPRT assay was only carried out on CHO cells, which is the cell line conventionally used for measuring HPRT mutagenesis [53]. Contrary to expectations, 
we found that veliparib, arsenic-trioxide, and spironolactone treatment decreased the number of cells carrying nonfunctional mutations in their HPRT gene after UVB exposure (Figure 3A,B,D,E). Higher concentrations of the treatment compounds decreased the mutation rates almost to baseline, which was surprising in light of the increased CPD content with the same agents $24 \mathrm{~h}$ after the UVB exposure. The fourth molecule, resveratrol, caused nonsignificant increases in UVB-induced mutagenesis (Figure 3C).

A

B
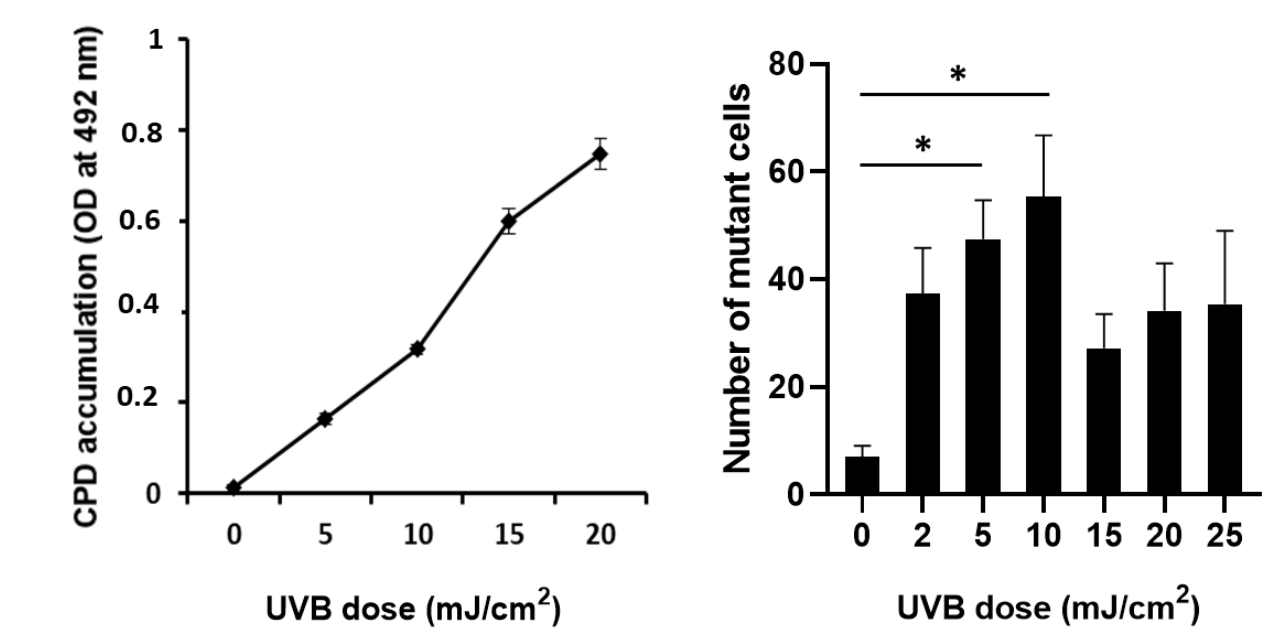

Figure 2. CPD accumulation and UVB-induced mutagenesis following different doses of UVB exposure. (A) Accumulation of CPD photolesions with increasing doses of UVB radiation in $\mathrm{CHO}$ cells. CPDs were detected $24 \mathrm{~h}$ after UVB exposure. Mean \pm SEM $(n=3)$. (B) Number of mutated cells in response to increasing doses of UVB radiation in CHO cells after a 10-day culture in selective medium containing 6-thioguanine. Mean $\pm \mathrm{SEM}, n=6$. ${ }^{*}$ indicates statistically significant difference at $p<0.05$.

\subsection{Resveratrol, Arsenic Trioxide, and Spironolactone Enhanced UVB-Induced Apoptosis}

While chemically induced attenuation of NER was triggered by the test compounds, some of them also showed marked anti-mutagenic activity. Therefore, we aimed to investigate other mechanisms that can affect UVB-induced mutations. Arsenic derivatives have well-known cytotoxic effects [56,57], especially in combination with other mutagens, such as UVB [58]. Apoptosis serves as a protective mechanism to diminish mutant clone formation [59]. Therefore, we hypothesized that the applied chemicals may induce an elevated photosensitive response in the UV-exposed cells, thereby inducing the clearance of cells with unrepaired DNA damage, resulting in decreased UVB-induced mutagenesis.

Because $10 \mathrm{~mJ} / \mathrm{cm}^{2} \mathrm{UVB}$ (used for HPRT mutagenesis assay) caused a very moderate decrease in cell viability (more than $80 \%$ of the cells left viable) (Figure S2), we decided to choose $20 \mathrm{~mJ} / \mathrm{cm}^{2}$ for apoptosis measurements. To verify that the UVB dose does not influence the effects of a chemical treatment on HPRT mutagenesis, we repeated HPRT mutation assays with two of the most anti-mutagenic treatments, $25 \mu \mathrm{M}$ ABT-888 and $25 \mu \mathrm{M}$ SP. Although $20 \mathrm{~mJ} / \mathrm{cm}^{2}$ was less mutagenic than $10 \mathrm{~mJ} / \mathrm{cm}^{2}$, the direction of the changes after inhibitor treatments remained the same (Figure S3).

$\mathrm{CHO}$ cells were pretreated with the drugs and exposed to UVB. Subsequently, i.e., $48 \mathrm{~h}$ after irradiation, cells were stained with Alexa Fluor 488-conjugated Annexin V (AV) and propidium iodide (PI). Viable, apoptotic, and necrotic subpopulations were determined by flow cytometry. Both arsenic-trioxide and spironolactone treatments increased the proportion of dead cells in response to UVB. At higher treatment concentrations $(4 \mu \mathrm{g} / \mathrm{mL}$ arsenic trioxide or $25 \mu \mathrm{M}$ spironolactone), the mean percentage of living cells was between $11 \%$ and $23 \%$. In the group exposed to UVB only, more than $50 \%$ of the cells were viable $48 \mathrm{~h}$ after the irradiation (Figure 4E-H). Resveratrol, the only tested molecule without detectable 
anti-mutagenic properties, induced only a mild increase in UV-induced apoptosis at high concentrations (Figure 4C,D); this is probably one of the reasons for the unaltered mutagenic response. Surprisingly, veliparib, a molecule with high DNA-repair-inhibitory properties and anti-mutagenic effects, caused no alterations in cell viability after UVB (Figure 4A,B). In HaCaT cells, we observed very similar alterations by the treatments (Figure S4); however, veliparib caused a mild decrease in cell viability in our previous study [29].

A

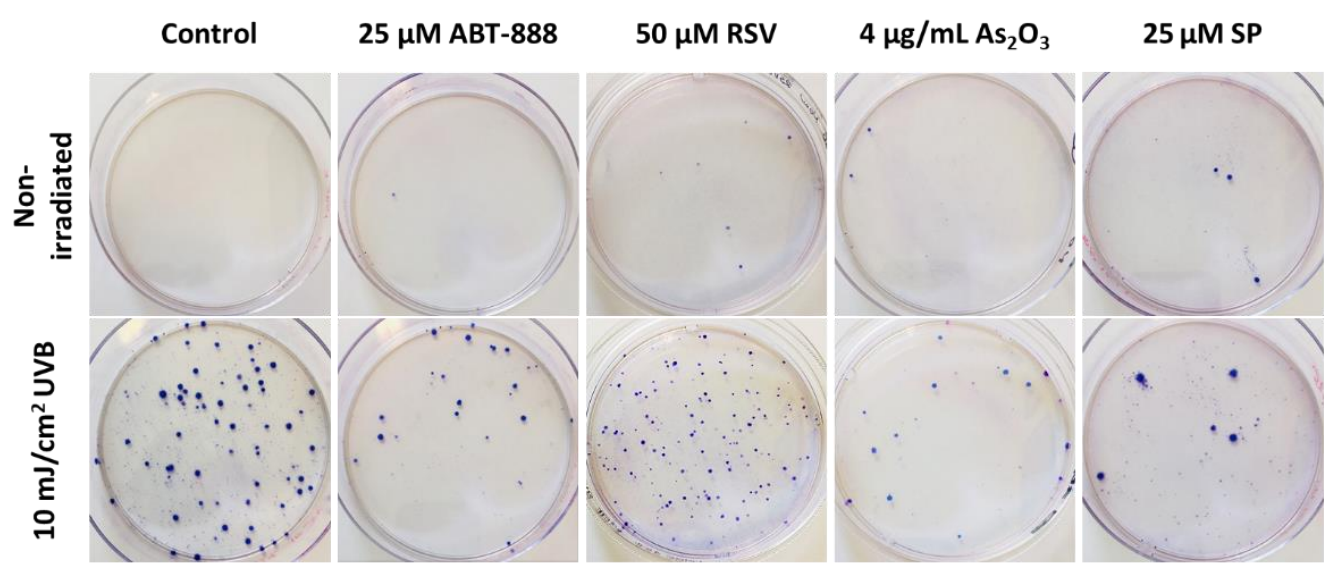

B

C

D

E
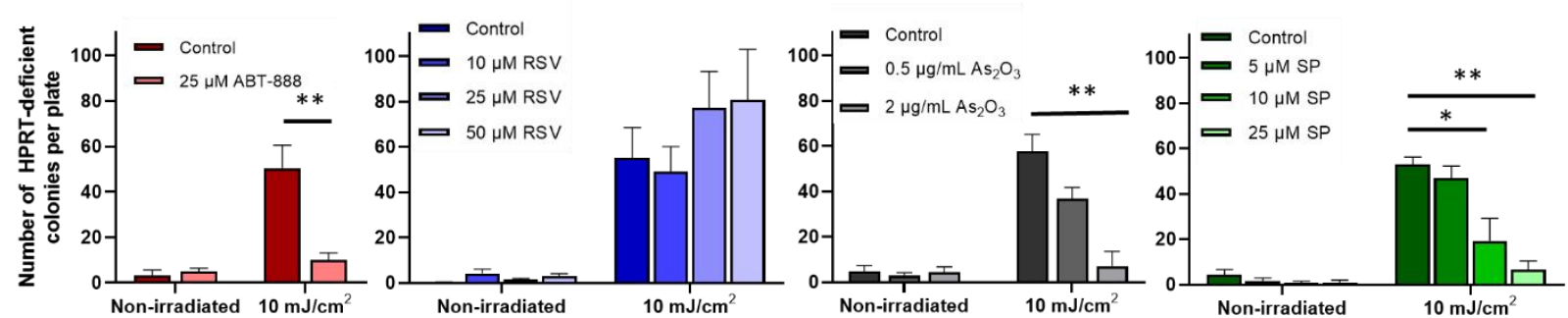

$\mathbf{F}$

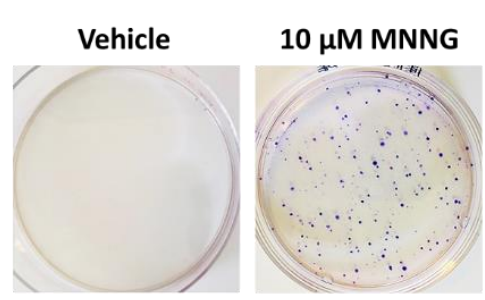

G

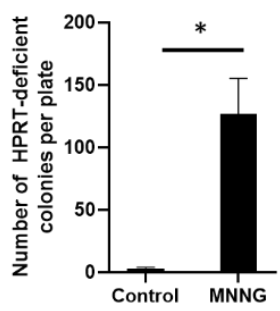

Figure 3. Effects of nucleotide excision repair (NER) inhibitors on UVB-induced HPRT gene mutation burden. (A) HPRT gene mutation assay after UVB and NER-inhibitor treatments. Cells were pretreated and exposed to $10 \mathrm{~mJ} / \mathrm{cm}^{2} \mathrm{UVB}$ radiation. HPRT mutant cells were selected in Dulbecco's modified Eagle media (DMEM) containing $5 \mu \mathrm{M}$ 6-thioguanine. One representative experiment from at least three independent measurements is presented. (B-E) Mean \pm SEM of $\geq 3$ HPRT gene mutation assays after treatment with (B) veliparib (ABT-888), (C) resveratrol (RSV), (D) arsenic trioxide $\left(\mathrm{As}_{2} \mathrm{O}_{3}\right)$, and (E) spironolactone (SP). (F,G) $10 \mu \mathrm{M}$ 1-methyl-3-nitro-1-nitrosoguanidine (MNNG) was used as a positive control for the assays. ${ }^{*}$ and ${ }^{* *}$ indicate statistically significant differences at $p<0.05$ and $p<0.01$. 

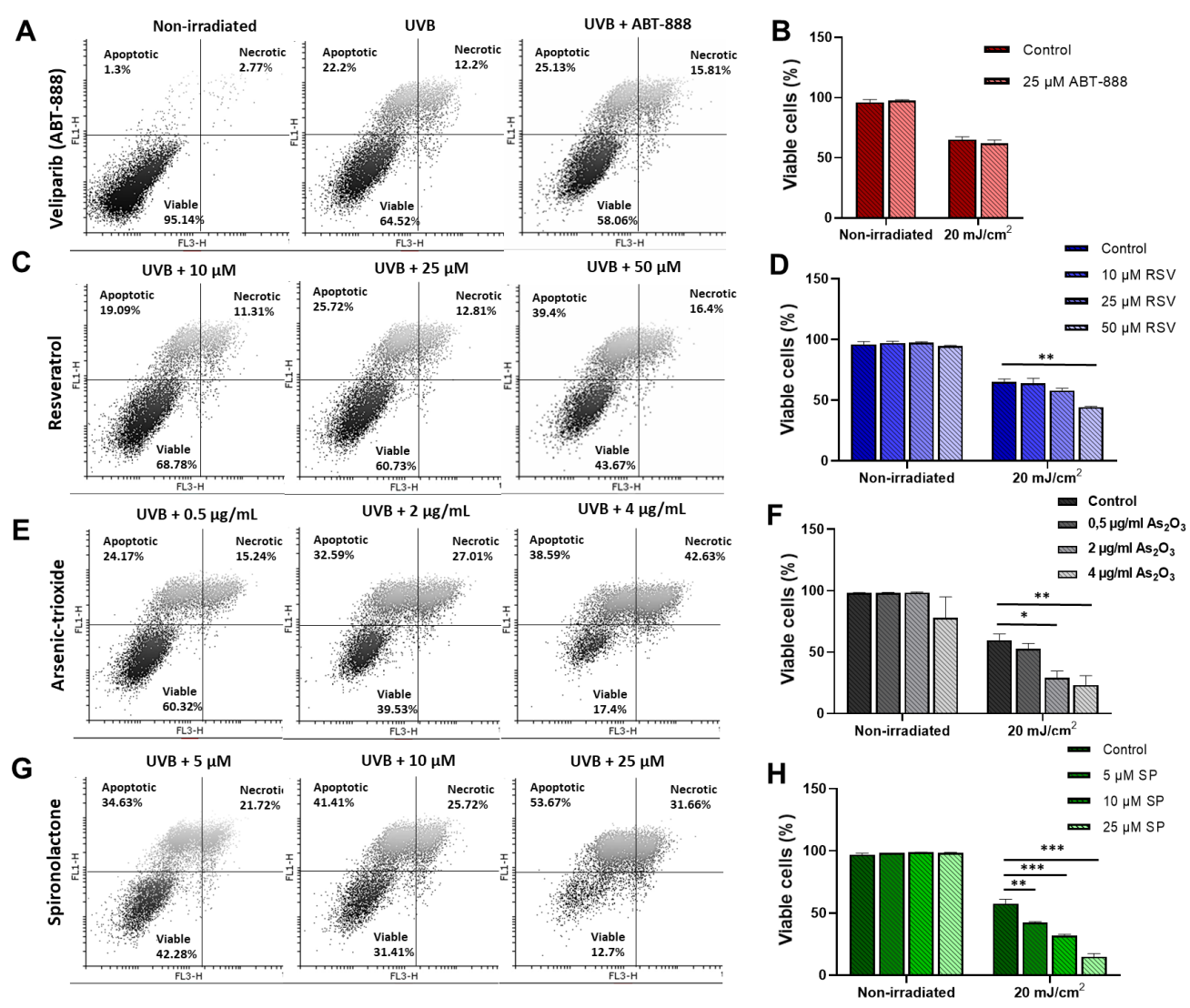

Figure 4. Changes in UVB-induced alterations in cell viability induced by pretreatment with NER-inhibitory molecules. Cells were pretreated with the indicated concentrations of (A,B) veliparib (ABT-888), (C,D) resveratrol (RSV), (E,F) arsenic trioxide $\left(\mathrm{As}_{2} \mathrm{O}_{3}\right)$, or $(\mathbf{G}, \mathbf{F})$ spironolactone (SP) and exposed to $20 \mathrm{~mJ} / \mathrm{cm}^{2} \mathrm{UVB}$ or left unexposed (nonirradiated). After $48 \mathrm{~h}$ of irradiation, apoptotic (Annexin $\mathrm{V}+$ /propidium iodide (PI-), necrotic (Annexin V+/PI+), and viable (Annexin V-/PI-) cells were detected by flow cytometry. $(\mathbf{B}, \mathbf{D}, \mathbf{F}, \mathbf{H})$ Bars represent the percentage of living cells $48 \mathrm{~h}$ after UVB exposure after inhibitor treatments. We calculated the mean \pm SEM of three independent experiments, where ${ }^{*}{ }^{* *}$, and ${ }^{* * *}$ denote statistically significant differences at $p<0.05, p<0.01$, and $p<0.001$.

\subsection{Veliparib and Resveratrol Augment UVB-Induced Cell Cycle Arrest}

Besides apoptosis, cell cycle arrest is one of the main cellular mechanisms that can attenuate the long-term effects of mutagenic exposure. During this process, cell division is halted in cells with unrepaired DNA lesions, extending the time for repair [60,61]. To assess whether the tested molecules can modify UVB-induced cell cycle arrest, we analyzed cell cycle progression of $\mathrm{CHO}$ cells 1,3 , and 6 days after $20 \mathrm{~mJ} / \mathrm{cm}^{2} \mathrm{UVB}$ exposure. One day post-UVB, a large number of cells was detected in the $\mathrm{G}_{2} / \mathrm{M}$ phases in every UV-irradiated group, consistent with previous findings showing that UVB-radiation-induced cell cycle arrest is mainly manifested at $\mathrm{G}_{2} / \mathrm{M}$ [62]. Restoration of the cell cycle began at 3 days after UVB exposure and was nearly indistinguishable from the nonirradiated group 6 days after UVB radiation. When cells were pretreated with $25 \mu \mathrm{M}$ veliparib, the percentage of cells in the $G_{2} / M$ phase showed a mild but statistically significant increase compared to that in the vehicle control. The increase lasted up to 6 days after the exposure (Figure 5A,B), suggesting that veliparib treatment extends the recovery time of cells from DNA damage, which possibly contributes to its anti-mutagenic effect. The increase of UVB-induced cell cycle block and decreased proliferative capacity after veliparib treatment were also observed in HaCaT cells [29]. Resveratrol also caused a moderate elevation in the $\mathrm{G}_{2} / \mathrm{M}$ block 3 days after the UVB, but this difference was only short-term and was not detectable 
6 days after UVB exposure (Figure 5C). HaCaT cells did not show change in cell cycle progression after resveratrol treatment (Figure S5). Arsenic-trioxide and spironolactone treatments did not affect cell cycle progression after UVB either in $\mathrm{CHO}$ (Figure S6A,B) or in HaCaT cells (Figure S6C,D).

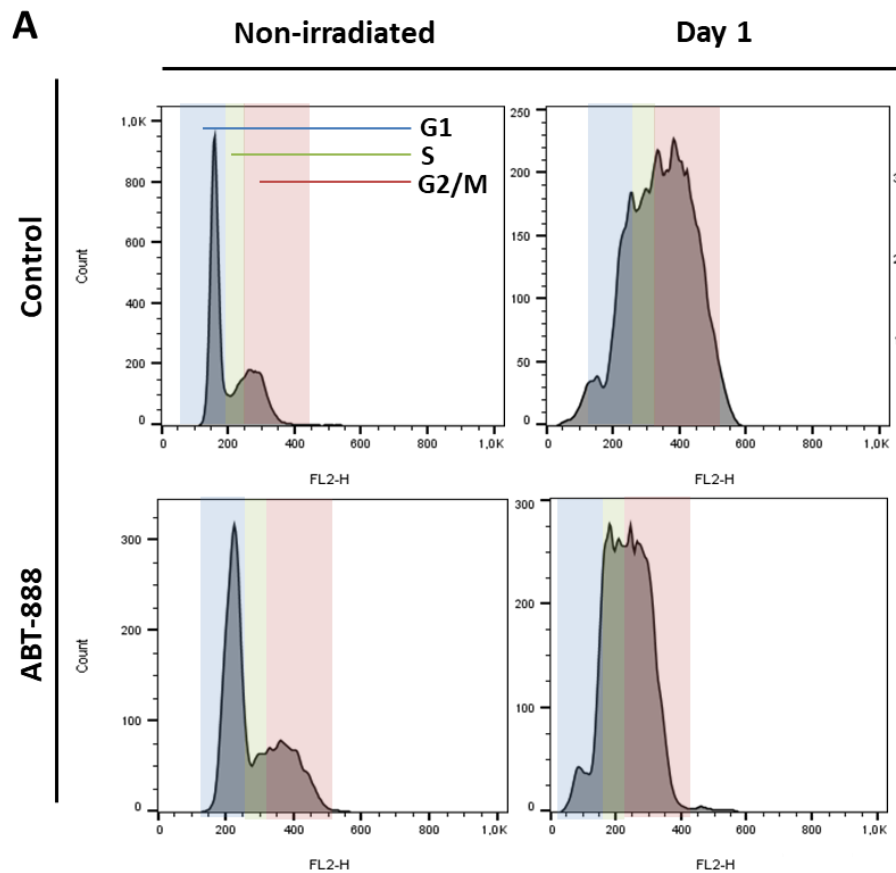

C
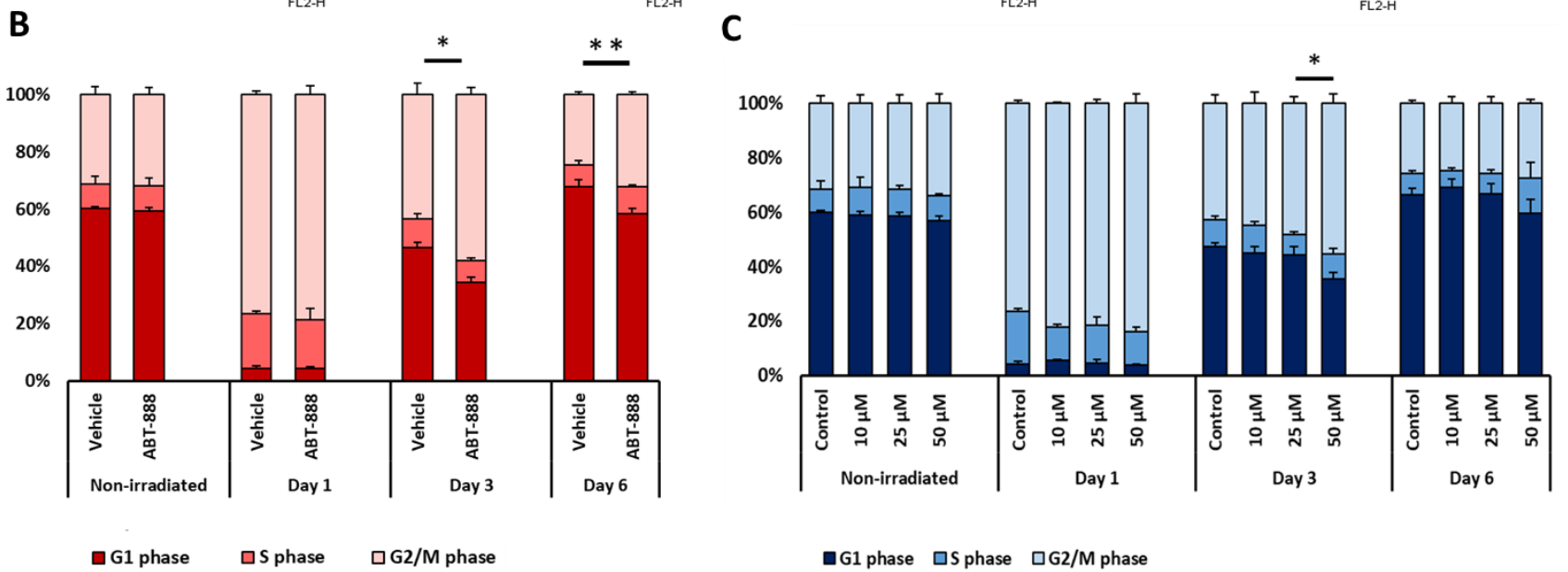

Figure 5. Cell cycle progression after veliparib and resveratrol treatment followed by UVB irradiation. (A) Cells were treated with $25 \mu \mathrm{M}$ veliparib (ABT-888) and exposed to $20 \mathrm{~mJ} / \mathrm{cm}^{2} \mathrm{UVB}$ or left unexposed (nonirradiated). Cell cycle progression was analyzed 1, 3, and 6 days after exposure using propidium-iodide staining followed by flow cytometry. G1 (blue), S (green), and G2/M (red) phase cell populations were distinguished, as indicated. (B) The distribution of cells in different phases was calculated after veliparib and (C) different doses of resveratrol treatment (mean \pm SEM; $n=3$ ). ${ }^{*}$ and ** denote statistically significant differences at $p<0.05$ and $p<0.01$, respectively.

\subsection{Altered Protein Expression in Diverse Stress-Response Pathways May Orchestrate UVB-Induced Mutagenesis}

We aimed to identify general upstream regulators at the protein level that can shed light on the anti-mutagenic nature of the compounds. Thus, we looked for changes in the expression or activation levels of proteins involved in key pathways linked to DNA damage with UVB-induced mutagenesis. First, we measured the phosphorylation level of p53 protein and the expression of the phosphatidylethanolamine conjugated form of 
microtubule-associated protein 1A/1B-light chain 3 protein (LC3-I-II). Phospho-p53 and LC3-I and II are widely accepted markers of DNA damage sensing and cellular autophagy, respectively $[63,64]$. Western blot analysis revealed that LC3-II expression was increased after UVB exposure, and veliparib treatment enhanced these effects $20 \mathrm{~h}$ post-UVB (Figure $6 \mathrm{~A}, \mathrm{~B}$ ). Thus, PARP1 inhibition by veliparib promotes UVB-induced autophagy [29]. Similar to LC3 expression, p53 phosphorylation levels increased after UVB irradiation and this effect was augmented by PARP inhibition (Figure 6A,C). Total p53 expression was also enhanced by UVB exposure, but veliparib treatment did not affect it (Figure 6A). No differences in LC3 expression (Figure S7A-C) or p53 phosphorylation levels (Figure S7D-F) were detected after resveratrol, spironolactone, or arsenic-trioxide treatments, suggesting that the observed cellular changes were mediated by p53-independent mechanisms in these cases.

A

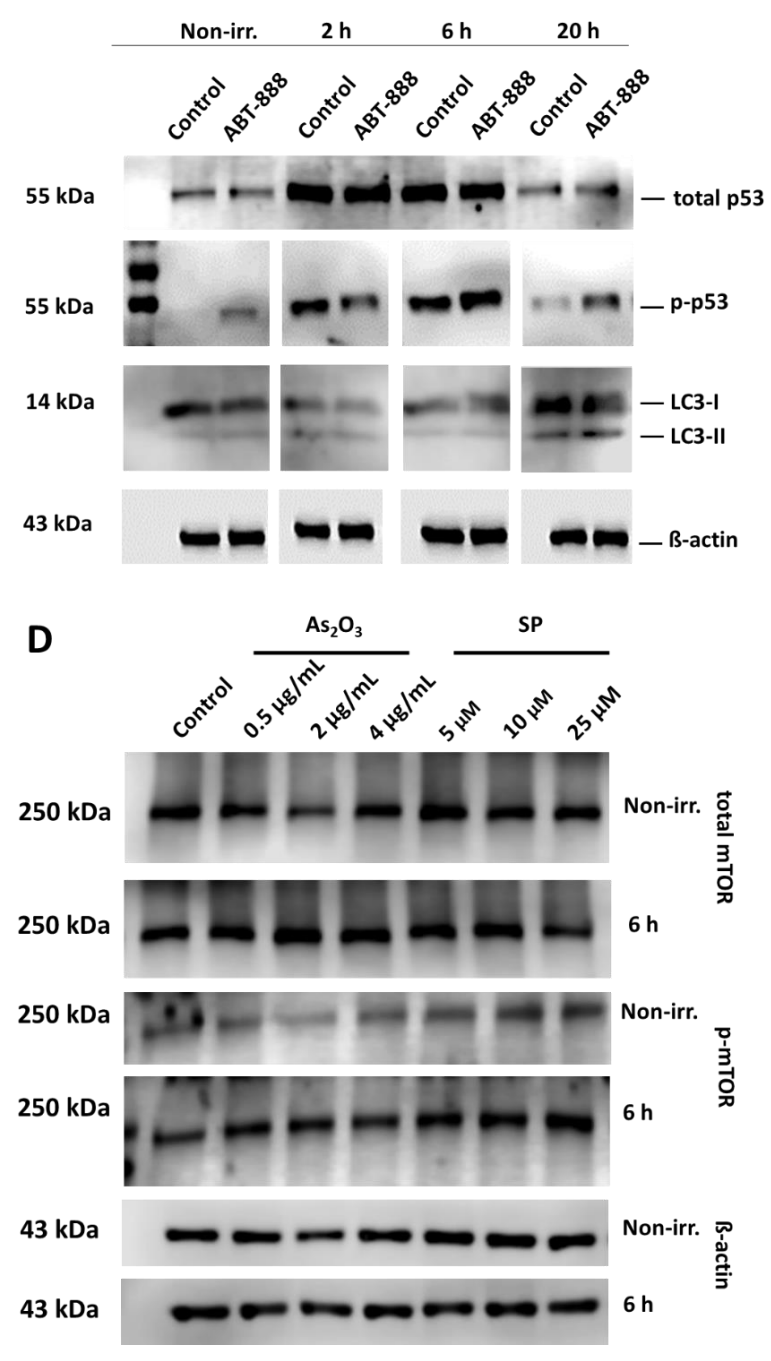

B

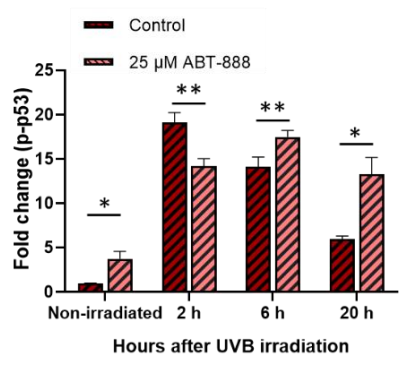

C

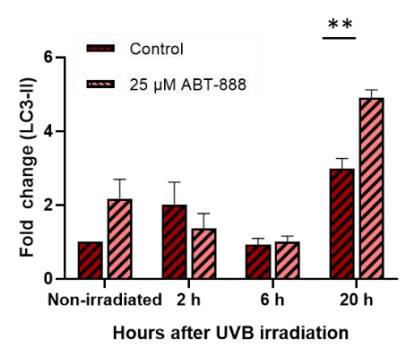

E

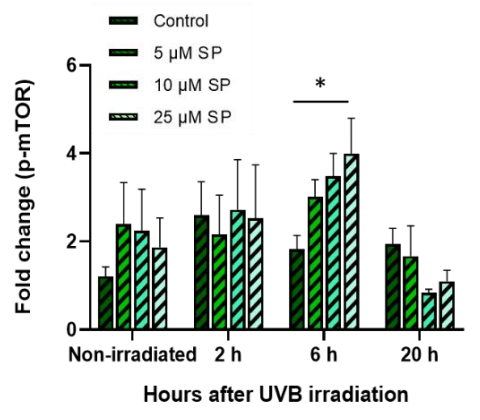

Figure 6. Protein expression and activation changes after veliparib (ABT-888), arsenic-trioxide $\left(\mathrm{As}_{2} \mathrm{O}_{3}\right)$, or spironolactone (SP) treatment followed by UVB irradiation. Cells were treated with $25 \mu \mathrm{M}$ veliparib (ABT-888) or different concentrations of $\mathrm{As}_{2} \mathrm{O}_{3}$ or SP and exposed to $20 \mathrm{~mJ} / \mathrm{cm}^{2} \mathrm{UVB}$ or left unexposed (nonirradiated). Control cells were UVB irradiated without any additional treatment. (A) Level of total tumor protein 53 (p53), phospho-p53 (p-p53) and microtubule-associated protein 1A/1B-light chain 3 protein (LC3-I and LC3-II) following ABT-888 treatment and (D) total mammalian target of rapamycin (mTOR) and phosphorylated mTOR (p-mTOR) (following SP or $\mathrm{As}_{2} \mathrm{O}_{3}$ treatment) were detected by Western blotting. Bars represent the mean of (B) $n=6$ for p53 phosphorylation; (C) $n=3$ for LC3-II expression after ABT-888 treatment and (E) $n=4$ for mTOR phosphorylation after $\mathrm{SP}$ or $\mathrm{As}_{2} \mathrm{O}_{3}$ treatment. Data were normalized to $\mathrm{B}$-actin. * and ${ }^{* *}$ denote statistically significant differences at $p<0.05$ and $p<0.01$, respectively. 
In addition to the p53 pathway, activation of the mammalian target of rapamycin (mTOR) signaling is another key mechanism for the regulation of diverse stress-response pathways, including apoptosis, senescence, and autophagy. In contrast to p53, phosphorylated mTOR promotes the survival and proliferation of UVB-exposed cells [65]. We found, that arsenic-trioxide and spironolactone treatments increased mTOR phosphorylation $6 \mathrm{~h}$ after UVB, but this increase was only statistically significant after spironolactone treatment. Total mTOR expression was not affected (Figure 6D,E). The other two chemicals did not affect mTOR phosphorylation after UVB (Figure S8A-C).

\section{Discussion}

Gross NER defects in XP patients result in accelerated photocarcinogenesis. Several human medications are effective inhibitors of NER [26,28,29,31], raising the possibility that the clinical application of these molecules enhances photocarcinogenesis. Although some of these molecules are widely used in clinical practice, in vivo therapeutic application of these compounds is not associated with increased risk of photocarcinogenesis $[35,66,67]$.

We confirmed that all these test molecules impair the elimination of CPD photolesions from DNA after UVB irradiation. Three molecules-veliparib, spironolactone, and arsenic trioxide- exerted strong anti-mutagenic effects (HPRT gene mutation assay), while resveratrol not affected UVB-induced mutation formation. Spironolactone and arsenic trioxide induced a marked loss in cell viability upon UVB exposure, while inhibition of PARP1 by veliparib caused a prolongation of UVB-induced cell cycle arrest.

The detected anti-mutagenic effects of the tested compounds could be interesting in the aspect of synthetic lethality, which is a promising therapeutical approach for the treatment of various cancers [68]. Inhibitors of PARP1 are already investigated due to their synthetic lethal effects with the combination of pre-existing BRCA1/2 (Breast Cancer gene 1/2) loss-of-function mutations $[69,70]$. Our findings that these inhibitors are able to reduce the survival of cells carrying mutations, also support the hypothesis that selective elimination of cancerous cells can be achieved by inducing defects in cellular repair pathways, supplementing the deleterious effects of other genetic deficiencies. The possibility of testing the other anti-mutagenic chemicals (besides veliparib) as synthetic lethal compounds should be also considered-especially in the case of spironolactone, which has markedly less harmful side effects compared to arsenic trioxide.

These results suggest, that possible synthetic lethal properties of the chemicals can originate from their ability to inhibit specific subunits of the NER complex. Although PARP1 is involved in the recognition of CPDs and thus in the initiation of the NER process through the activation of DDB2 (DNA damage-binding protein 2) [71,72] and XPC (Xeroderma pigmentosum, complementation group C) [73], this multi-faceted protein also plays a role in the regulation of other repair pathways. For example, PARP1 has been shown to interact with CSB (Cockayne syndrome group B), a protein involved in both transcriptioncoupled NER and base excision repair (BER) [71,74]. Thus, its synthetic lethality is may be linked to a complex dysregulation of DNA repair. In contrast, spironolactone was found to inhibit NER by inducing the rapid proteosomal degradation of the XPB (Xeroderma pigmentosum, complementation group B) subunit [31,32], which suggests a more specific interaction between pre-existing mutations and defective NER repair resulting in the elimination of genetically damaged cells. Arsenic trioxide was also shown to inhibit the XPC subunit [28,50], but this molecule has other versatile effects. For instance, arsenic trioxide regulates the survival of damaged cells through the induction of Bax/caspase-3 pathway [57,75], ROS (relative oxygen species) production [57], and the downregulation of survivin [75]. Thus, its lethal effects on UV-exposed cells cannot be merely explained by XPC inhibition. The underlying mechanism of resveratrol-induced defect in CPD removal is less known, but Keuser et al. found a significant compaction of the chromatin structure after resveratrol treatment. Resveratrol induces the activation of sirtuins (SIRTs), which are members of the class III histone deacetylases (HDACs), and regulates various cellular pathways including DNA damage recognition and repair through the deacetylation of 
target proteins. Furthermore, deacetylation-mediated chromosome remodeling via SIRTs may influence the accessibility of repair proteins to the damaged DNA and result in the accumulation of CPDs and other types of DNA lesions, as well [26].

P53 is considered to be the guardian of the genome; it regulates the balance between pro- and anti-apoptotic signals during the stress response [64]. In our study, veliparib significantly enhanced UV-induced p53 phosphorylation. This is intriguing in the view of other studies, which found that the application of PARP1 inhibitors in cancer therapy is more effective in p53-deficient cells [76,77]. This is a result of direct interaction between PARP1 and p53 protein, where the status of p53 (gain-of function/loss-of-function) dictates the outcome of cell survival. For example, loss-of-function mutations of p53 were associated with higher sensitivity to PARPi (inhibitor of poly-(adenosine diphosphate [ADP]) ribose polymerase) [78-80]. These results suggest that increased activation or gain-of-function mutation of p53 following chemically induced PARP1 inhibition may serve to protect cells from intensive genome instability due to the loss of PARP1 function.

Except veliparib, none of the other molecules caused significant alterations in p53 phosphorylation, suggesting that changes are at least partly mediated by p53-independent pathways in these cases. The phosphorylation of mTOR, involved in cell survival, was increased by spironolactone, in contradiction to the strong apoptotic response. We hypothesize that increased mTOR phosphorylation is a cellular strategy to counteract the cytotoxic effect of SP.

Autophagy represents another key strategy in cell survival [64], which was enhanced by ABT-888 treatment. However, the role of autophagy in tumorigenesis is quite controversial. While autophagy helps remove damaged cellular organelles and thereby prevents tumor formation, it can also fuel metabolism by recycling damaged molecules to promote the survival of pre-cancerous cells during metabolic stress in a nutrient-deficient environment [81].

We observed that the mutagenic effect of UVB and CPD accumulation did not exhibit parallel increases, as UVB-induced mutagenesis decreased at higher UVB doses. This shows that there is no obligate linear relationship between repair activity and UVB mutagenesis, but other factors should be also considered while assessing the possible risk of skin cancer induction by a chemical treatment. Alterations in the cellular UVB response, such as elevated apoptosis, cell cycle arrest, and autophagy, may play a significant role in counterbalancing the negative effect of repair inhibition on mutagenesis.

In conclusion, we demonstrated that UVB-induced mutagenesis is a highly complex process even in an in vitro model, and decreased cellular repair activity does not necessarily result in elevated mutagenicity. These results suggest that, if a molecule inhibits DNA repair in vitro, its effects on other cellular processes also need to be assessed before its mutagenic potential can be predicted. Furthermore, DNA repair inhibitors need not be considered necessarily mutagenic. We also showed that three out of four compounds reduced UVB-induced mutagenesis in vitro, which suggest that further in vivo studies are warranted to establish the safety of these molecules.

\section{Materials and Methods}

\subsection{Cell Culture}

CHO-K1 (Chinese hamster ovary; ATCC, Manassas, VA, USA) and HaCaT (immortalized human keratinocyte; ATCC, Manassas, VA, USA) cells were cultured in $4500 \mathrm{mg} / \mathrm{L}$ glucose containing Dulbecco's modified Eagle media (DMEM, Biosera, Budapest, Hungary) supplemented with L-glutamine (Biosera, Budapest, Hungary), 10\% heat-inactivated fetal bovine serum (FBS; Biosera, Budapest, Hungary), and $0.5 \%$ antibiotic/antimycotic solution (Biosera, Budapest, Hungary). Cells were maintained in a humidified incubator at $37^{\circ} \mathrm{C}$ with $5 \% \mathrm{CO}_{2}$ atmosphere. 


\subsection{Cell Treatment}

Cells were harvested with trypsin-EDTA (Biosera, Budapest, Hungary) and then seeded in six-well plates for the hypoxanthine phosphoribosyltransferase (HPRT) gene mutation assay or 24-well plates for all other experiments. At $80 \%$ confluence, cells were pretreated with $25 \mu \mathrm{M}$ ABT-888 (PARP1 inhibitor, veliparib, Selleckchem, Houston, TX, USA), 10-50 $\mu \mathrm{M}$ resveratrol (Abcam, Cambridge, UK), 5-25 $\mu \mathrm{M}$ spironolactone (Selleckchem, Houston, TX, USA), or 0.5-4 $\mu \mathrm{g} / \mathrm{mL} \mathrm{As}_{2} \mathrm{O}_{3}$ (Sigma-Aldrich, St. Louis, MO, USA) solution. In the case of veliparib treatment, we chose the concentration that caused marked inhibition of PARP1 protein, according to our previous [29] and current experiments (Figure S9). For the other chemicals, we identified three different concentrations due to their more complex and not fully understood mode of action - based on prior published data [26,27,30-32]. $\mathrm{As}_{2} \mathrm{O}_{3}$ was dissolved in $1 \mathrm{M} \mathrm{NaOH}$ (Sigma-Aldrich, St. Louis, MO, USA) and diluted in Dulbecco's phosphate-buffered saline (DPBS; Biosera, Budapest, Hungary). Other chemicals were dissolved in dimethyl sulfoxide (DMSO, Sigma-Aldrich, St. Louis, MO, USA). Pretreated cells were incubated for $120 \mathrm{~min}$ at $37^{\circ} \mathrm{C}$ before UVB irradiation.

\subsection{UVB Irradiation}

After pretreatment and incubation, the culture medium was removed, and cells were covered with a thin layer of DPBS. Cells were irradiated with $20 \mathrm{~mJ} / \mathrm{cm}^{2} \mathrm{UVB}$, using two UVB broadband tubes (TL-20W/12 RS; Philips, Eindhoven, The Netherlands). For the HPRT gene mutation assay, the UVB dose was reduced to $10 \mathrm{~mJ} / \mathrm{cm}^{2}$, as it was found to be the most mutagenic for $\mathrm{CHO}$ cells (Figure 2). The proper dosage of UVB was determined by a UVX Digital Radiometer (UVP Inc., San Gabriel, CA, USA). After irradiation, the DPBS was replaced by DMEM supplemented as described above.

\subsection{CPD-Specific Enzyme-Linked Immunosorbent Assay (ELISA)}

A CPD-specific ELISA was performed as previously described by Boros et al. [82]. Genomic DNA was extracted by an Invitrogen ${ }^{\mathrm{TM}}$ PureLink ${ }^{\mathrm{TM}}$ Genomic DNA Mini Kit (Thermo Fisher Scientific, Waltham, MA, USA) $24 \mathrm{~h}$ after the UVA irradiation. Flat-bottomed 96-well plates were coated with $0.003 \%$ protamine-sulfate and incubated at $37^{\circ} \mathrm{C}$ to completely dry. DNA was denatured at $100{ }^{\circ} \mathrm{C}$ for $10 \mathrm{~min}$, then immediately chilled on ice for $15 \mathrm{~min}$. Denatured DNA was distributed to wells in triplicate (15 ng DNA to each well) and incubated at $37^{\circ} \mathrm{C}$ overnight. Plates were washed with PBS (Biosera, Budapest, Hungary) containing 0.05\% Tween-20 (Amresco, Solon, OH, USA) (PBS-T) and incubated with $150 \mu \mathrm{L} /$ well $5 \%$ FBS at $37^{\circ} \mathrm{C}$ for $30 \mathrm{~min}$ to prevent nonspecific antibody binding. After washing plates three times with PBS-T, anti-CPD monoclonal antibody (clone TDM-2, dilution 1:1500, Cosmo Bio Co., Ltd., Tokyo, Japan) was added to each well. Plates were incubated at $37^{\circ} \mathrm{C}$ for $60 \mathrm{~min}$. After washing three times, HRP-conjugated anti-mouse IgG secondary antibody (dilution 1:3000, Bio-Rad, Hercules, CA, USA) was added and plates were incubated at $37^{\circ} \mathrm{C}$ for $30 \mathrm{~min}$. Plates were washed three times with PBS-T and once with $150 \mu \mathrm{L} /$ well citrate-phosphate buffer $\left(0.51 \% \mathrm{C}_{6} \mathrm{H}_{8} \mathrm{O}_{7} . \mathrm{H}_{2} \mathrm{O}\right.$ (Sigma-Aldrich, St. Louis, MO, USA) and $0.73 \% \mathrm{Na}_{2} \mathrm{HPO}_{4}$ (Sigma-Aldrich, St. Louis, MO, USA) in distilled water; $\mathrm{pH} 5.0$ ). Substrate solution (0.04\% o-phenylenediamine (Sigma-Aldrich, St. Louis, MO, USA) and $0.006 \%$ $\mathrm{H}_{2} \mathrm{O}_{2}$ (Sigma-Aldrich, St. Louis, MO, USA) dissolved in citrate-phosphate buffer with $\mathrm{H}_{2} \mathrm{O}_{2}$ added to the solution, when o-phenylenediamine was completely dissolved) was added to each well. Plates were incubated until the appropriate color intensity appeared. To stop the enzyme reaction, $50 \mu \mathrm{L} /$ well $2 \mathrm{~N} \mathrm{H}_{2} \mathrm{SO}_{4}$ (Sigma-Aldrich, St. Louis, MO, USA) was added to each well. Absorbance was measured at $492 \mathrm{~nm}$ using an Epoch Microplate Spectrophotometer (BioTek, Budapest, Hungary).

\subsection{HPRT Gene Mutation Assay}

$\mathrm{CHO}$ cells were cultured in DMEM containing HAT (hypoxanthine-aminopterinthymidine; HAT Media Supplement $(50 \times)$ Hybri-Max ${ }^{\mathrm{TM}}$; Sigma-Aldrich, St. Louis, MO, USA) for a week to eliminate preexisting HPRT-mutant cells from the culture. CHO cells 
were treated with the previously specified inhibitor molecules and exposed to $0-25 \mathrm{~mJ} / \mathrm{cm}^{2}$ UVB. Cells were cultured for one more week and then harvested with trypsin-EDTA (Biosera, Budapest, Hungary). In the case of each sample, an equal number of cells $\left(1 \times 10^{6}\right)$ were seeded into $100 \mathrm{~mm}$ Petri dishes in selective DMEM containing $5 \mu \mathrm{M}$ 6-thioguanine (6-TG; Sigma-Aldrich, St. Louis, MO, USA). The 6-TG-resistant cells were allowed to form visible clones for 10 days. Clones were washed with PBS, fixed with $100 \%$ methanol (Sigma-Aldrich, St. Louis, MO, USA) for $10 \mathrm{~min}$, and stained with May-Grünwald-Giemsa (Molar Chemicals, Halásztelek, HU, Hungary). HPRT-mutant colonies were counted. For the positive control, $10 \mu \mathrm{M}$ 1-methyl-3-nitro-1-nitrosoguanidine (MNNG; TCI Europe N.V., Zwijndrecht, Belgium) was used.

\subsection{Apoptosis Assay}

Cell viability was measured $48 \mathrm{~h}$ after UVB irradiation using Alexa Fluor 488-conjugated Annexin V/propidium iodide (PI) dual staining (apoptosis assay, Alexa Fluor ${ }^{\mathrm{TM}} 488$ Annexin V/Dead Cell Apoptosis Kit, Thermo Fisher Scientific, Waltham, MA, USA). The supernatant of the cells was collected, living cells were harvested with trypsin-EDTA and added to the supernatant. To avoid the loss of apoptotic cells, cell culture media was not changed between UVB exposure and viability measurement. Cells were labeled according to the manufacturer's instructions. Cells were analyzed by flow cytometry using a FACS Calibur (Becton Dickinson, San Jose, CA, USA) flow cytometer and CellQuestPro software 5.2 (Becton Dickinson, San Jose, CA, USA). Fluorescence intensity was measured in the FL-1 (for Annexin V) and FL-3 (for PI) channels. For data evaluation, FlowJo 10.6.2. (Becton Dickinson, San Jose, CA, USA) flow cytometry software was used.

\subsection{Cell Cycle Analysis}

Cell cycle progression was quantified 1,3, and 6 days after UVB irradiation. Cells were harvested with trypsin-EDTA, washed with DPBS, and fixed with ice-cold $80 \%$ ethanol (VWR, Radnor, PA, USA). Equal numbers of cells were centrifuged at $3500 \mathrm{rpm}$, for $5 \mathrm{~min}$ and re-suspended in $50 \mu \mathrm{L}$ DPBS containing $0.2 \mathrm{mg} / \mathrm{mL}$ RNase A (Sigma-Aldrich, St. Louis, $\mathrm{MO}$, USA), $0.1 \mu \mathrm{L}$ Triton-X 100 (Amresco, Solon, $\mathrm{OH}, \mathrm{USA}$ ), and $5 \mathrm{mg} / \mathrm{mL}$ PI (Thermo Fisher Scientific, Waltham, MA, USA). Samples were incubated at $37^{\circ} \mathrm{C}$ for $45 \mathrm{~min}$ and then supplemented with $0.5 \%$ bovine serum albumin (BSA; VWR, Radnor, PA, USA). Cell cycle progression was analyzed by flow cytometry with an FACS Calibur and fluorescence was measured on the $x$-axis in the FL2-A channel. Doublet discrimination was performed for single-cell analysis. FlowJo software was used for analyzing the data.

\subsection{Western Blot}

Cells were lysed in RIPA (Radioimmunoprecipitation assay) buffer containing proteaseinhibitor cocktail (dilution 1:1000) 2, 6, or $24 \mathrm{~h}$ after UVB irradiation. Lysates were centrifuged at $15,000 \mathrm{rpm}$ for $5 \mathrm{~min}$ at $4{ }^{\circ} \mathrm{C}$. Protein concentration in the supernatants was measured using a Pierce BCA (Bicinchoninic acid) assay kit (Thermo Fisher Scientific, Waltham, MA, USA). Protein samples were mixed with $5 \times$ loading buffer (bromophenol blue ( $0.25 \%)$, $\beta$-mercaptoethanol ( $5 \%$; Sigma-Aldrich, St. Louis, MO, USA), glycerol ( $50 \%$; Sigma-Aldrich, St. Louis, MO, USA), SDS (sodium dodecyl sulfate; $10 \%$; Duchefa Biochemie, Haarlem, The Neatherlands), Tris- $\mathrm{HCl}$ (0.25 M, pH 6.8; Sigma-Aldrich, St. Louis, MO, USA)), then boiled at $100{ }^{\circ} \mathrm{C}$ for $10 \mathrm{~min}$. Proteins were separated on $7.5 \%, 10 \%$, or $12.5 \%$ polyacrylamide gels, then transferred to nitrocellulose membranes (Bio-Rad, Hercules, CA, USA). Membranes were washed in TBS-T (TBS buffer containing 0.05\% Tween-20), blocked in $5 \%$ nonfat dry milk for $1 \mathrm{~h}$, and incubated with the primary antibody overnight at $4{ }^{\circ} \mathrm{C}$. Antibodies used for Western blotting are listed in Supplementary Table S1. Antibodies were diluted in TBS-T containing 5\% BSA. After washing with TBS-T, membranes were incubated with horseradish peroxidase (HRP)-conjugated goat anti-mouse/anti-rabbit IgG secondary antibodies (Bio-Rad, Hercules, CA, USA; dilution 1:2000) for $1 \mathrm{~h}$ with gentle shaking. After washing, protein bands were visualized using Pierce ${ }^{\mathrm{TM}} \mathrm{ECL}$ Western 
Blotting Substrate (Thermo Fisher Scientific, Waltham, MA, USA) or SuperSignal West Femto Maximum Sensitivity Substrate (Thermo Fisher Scientific, Waltham, MA, USA). For band quantification, ImageJ 1.8.0 software (Research Services Branch, National Institute of Mental Health, Bethesda, MD, USA) was used.

\subsection{Statistical Analysis}

The normality of the population was determined using the Shapiro-Wilk test. If two groups were compared, we used independent t-test (two tailed), as the Shapiro-Wilk test showed normal distribution. When we compared three or more groups, one-way ANOVA complemented by Dunnett's post-hoc test was used, if the data showed normal distribution. Kruskal-Wallis test complemented with Dunn's post hoc test was performed, if the distribution of the data was not normal. Statistical calculations were performed using GraphPad Prism 7 (GraphPad Software Inc., San Diego, CA, USA) and SPSS 25 software. (SPSS package for Windows, Release 25.; SPSS, Chicago, IL, USA). Data are presented as mean \pm SEM. Statistically significant differences are denoted by ${ }^{*}, * *$, and ${ }^{* * *}$ for $p<0.05$, $p<0.01$, and $p<0.001$.

Supplementary Materials: Supplementary Materials can be found at https://www.mdpi.com/1422 $-0067 / 22 / 4 / 1638 / s 1$.

Author Contributions: Conceptualization: É.R., E.F., and G.P.; methodology: E.F. and C.H.; formal analysis: E.A.J.; writing—original draft preparation: E.F.; writing, reviewing, and editing: C.H., É.R., G.E., and G.P.; funding acquisition: É.R.; supervision: É.R. All authors have read and agreed to the published version of the manuscript.

Funding: This work was supported by the European Union and the European Regional Development Fund GINOP-2.3.2-15-2016-00005; the Hungarian National Research Development and Innovation Fund NKFIH K120206; and the ÚNKP-20-4-I New National Excellence Program of the Ministry for Innovation and Technology from the source of the National Research, Development, and Innovation Fund.

Institutional Review Board Statement: Not applicable.

Informed Consent Statement: Not applicable.

Data Availability Statement: Not applicable.

Conflicts of Interest: The authors declare no conflict of interest. G.P. is a consultant for ADC Therapeutics and Buffalo Biolabs.

$\begin{array}{ll}\text { Abbreviations } \\ \text { 6-4PP } & \text { Pyrimidine (6-4) pyrimidone photoproduct } \\ \mathrm{ABT}^{-888} & \text { Veliparib } \\ \mathrm{As}_{2} \mathrm{O}_{3} & \text { Arsenic trioxide } \\ \mathrm{CHO} & \text { Chinese hamster ovary cell line } \\ \mathrm{CPD} & \text { Cyclobutane-pyrimidine dimer } \\ \mathrm{HPRT} & \text { Hypoxanthine phosphoribosyltransferase 1 } \\ \text { LC3 } & \text { Microtubule-associated protein 1A/1B-light chain } 3 \\ \text { mTOR } & \text { mammalian target of rapamycin } \\ \text { NER } & \text { Nucleotide excision repair } \\ \text { p53 } & \text { Cellular tumor antigen p53 } \\ \text { PARP1 } & \text { Poly [ADP-ribose] polymerase 1 } \\ \text { RSV } & \text { Resveratrol } \\ \text { SP } & \text { Spironolactone } \\ \text { XP } & \text { Xeroderma pigmentosum } \\ \text { UVB } & \text { Ultraviolet B radiation }\end{array}$




\section{References}

1. Olsen, C.; Green, A.C.; Pandeya, N.; Whiteman, D. Trends in Melanoma Incidence Rates in Eight Susceptible Populations through 2015. J. Investig. Dermatol. 2019, 139, 1392-1395. [CrossRef]

2. Glazer, A.M.; Winkelmann, R.R.; Farberg, A.S.; Rigel, D.S. Analysis of Trends in US Melanoma Incidence and Mortality. JAMA Dermatol. 2017, 153, 225-226. [CrossRef]

3. Sacchetto, L.; Zanetti, R.; Comber, H.; Bouchardy, C.; Brewster, D.; Broganelli, P.; López, M.D.C.; Coza, D.; Galceran, J.; Gavin, A.; et al. Trends in incidence of thick, thin and in situ melanoma in Europe. Eur. J. Cancer 2018, 92, 108-118. [CrossRef] [PubMed]

4. Apalla, Z.; Lallas, A.; Sotiriou, E.; Lazaridou, E.; Ioannides, D. Epidemiological trends in skin cancer. Dermatol. Pract. Concept. 2017, 7, 1-6. [CrossRef] [PubMed]

5. Griffin, L.L.; Ali, F.R.; Lear, J. Non-melanoma skin cancer. Clin. Med. 2016, 16, 62-65. [CrossRef]

6. Boukamp, P. Non-melanoma skin cancer: What drives tumor development and progression? Carcinogenesis 2005, 26, 1657-1667. [CrossRef]

7. de Zwaan, S.E.; Haass, N.K. Genetics of basal cell carcinoma. Australas J. Dermatol. 2010, 51, 81-92. [CrossRef]

8. Emri, G.; Paragh, G.; Tósaki, Á.; Janka, E.; Kollár, S.; Hegedûs, C.; Gellén, E.; Horkay, I.; Koncz, G.; Remenyik, É. Ultraviolet radiation-mediated development of cutaneous melanoma: An update. J. Photochem. Photobiol. B Biol. 2018, 185, 169-175. [CrossRef] [PubMed]

9. de Lima-Bessa, K.M.; Armelini, M.G.; Chiganças, V.; Jacysyn, J.F.; Amarante-Mendes, G.P.; Sarasin, A.; Menck, C.F.M. CPDs and 6-4PPs play different roles in UV-induced cell death in normal and NER-deficient human cells. DNA Repair 2008, 7, $303-312$. [CrossRef]

10. Pfeifer, G.P.; You, Y.-H.; Besaratinia, A. Mutations induced by ultraviolet light. Mutat. Res. 2005, 571, 19-31. [CrossRef]

11. Brash, D.E. UV signature mutations. Photochem. Photobiol. 2015, 91, 15-26. [CrossRef] [PubMed]

12. Lo, H.-L.; Nakajima, S.; Ma, L.; Walter, B.; Yasui, A.; Ethell, D.W.; Owen, L.B. Differential biologic effects of CPD and 6-4PP UV-induced DNA damage on the induction of apoptosis and cell-cycle arrest. BMC Cancer 2005, 5, 135. [CrossRef]

13. Meador, J.A.; Walter, R.B.; Mitchell, D.L. Induction, Distribution and Repair of UV Photodamage in the Platyfish, Xiphophorus signum. Photochem. Photobiol. 2000, 72, 260-266. [CrossRef]

14. Wei, L.; Christensen, S.R.; Fitzgerald, M.E.; Graham, J.; Hutson, N.D.; Zhang, C.; Huang, Z.; Hu, Q.; Zhan, F.; Xie, J.; et al. Ultradeep sequencing differentiates patterns of skin clonal mutations associated with sun-exposure status and skin cancer burden. Sci. Adv. 2021, 7, eabd7703. [CrossRef]

15. You, Y.H.; Szabó, P.E.; Pfeifer, G.P. Cyclobutane pyrimidine dimers form preferentially at the major p53 mutational hotspot in UVB-induced mouse skin tumors. Carcinogenesis. 2000, 21, 2113-2117. [CrossRef] [PubMed]

16. Scharer, O.D. Nucleotide excision repair in eukaryotes. Cold Spring Harb. Perspect. Biol. 2013, 5, a012609. [CrossRef] [PubMed]

17. Nakagawa, A.; Kobayashi, N.; Muramatsu, T.; Yamashina, Y.; Shirai, T.; Hashimoto, M.W.; Ikenaga, M.; Mori, T. Three-dimensional visualization of ultraviolet-induced DNA damage and its repair in human cell nuclei. J. Investig. Dermatol. 1998, 110, 143-148. [CrossRef] [PubMed]

18. Jans, J.; Schul, W.; Sert, Y.-G.; Rijksen, Y.; Rebel, H.; Eker, A.P.; Nakajima, S.; Van Steeg, H.; De Gruijl, F.R.; Yasui, A.; et al. Powerful skin cancer protection by a CPD-photolyase transgene. Curr. Biol. 2005, 15, 105-115. [CrossRef] [PubMed]

19. de Boer, J.; Hoeijmakers, J.H. Nucleotide excision repair and human syndromes. Carcinogenesis 2000, 21, 453-460. [CrossRef] [PubMed]

20. Chhabra, G.; Garvey, D.R.; Singh, C.K.; Mintie, C.A.; Ahmad, N. Effects and Mechanism of Nicotinamide Against UVA- and/or UVB-mediated DNA Damages in Normal Melanocytes. Photochem. Photobiol. 2019, 95, 331-337. [CrossRef]

21. Surjana, D.; Halliday, G.M.; Damian, D.L. Nicotinamide enhances repair of ultraviolet radiation-induced DNA damage in human keratinocytes and ex vivo skin. Carcinogenesis 2013, 34, 1144-1149. [CrossRef] [PubMed]

22. Katiyar, S.K.; Vaid, M.; Van Steeg, H.; Meeran, S.M. Green tea polyphenols prevent UV-induced immunosuppression by rapid repair of DNA damage and enhancement of nucleotide excision repair genes. Cancer Prev. Res. 2010, 3, 179-189. [CrossRef] [PubMed]

23. Chang, L.; Sheu, H.; Huang, Y.S.; Tsai, T.R.; Kuo, K. A novel function of emodin: Enhancement of the nucleotide excision repair of UV- and cisplatin-induced DNA damage in human cells. Biochem. Pharmacol. 1999, 58, 49-57. [CrossRef]

24. Vaid, M.; Sharma, S.D.; Katiyar, S.K. Proanthocyanidins inhibit photocarcinogenesis through enhancement of DNA repair and xeroderma pigmentosum group A-dependent mechanism. Cancer Prev. Res. 2010, 3, 1621-1629. [CrossRef] [PubMed]

25. Guillermo-Lagae, R.; Deep, G.; Ting, H.; Agarwal, C.; Agarwal, R. Silibinin enhances the repair of ultraviolet B-induced DNA damage by activating p53-dependent nucleotide excision repair mechanism in human dermal fibroblasts. Oncotarget 2015, 6, 39594-39606. [CrossRef]

26. Keuser, B.; Khobta, A.; Galle, K.; Anderhub, S.; Schulz, I.; Pauly, K.; Epe, B. Influences of histone deacetylase inhibitors and resveratrol on DNA repair and chromatin compaction. Mutagenesis 2013, 28, 569-576. [CrossRef]

27. Okui, T.; Fujiwara, Y. Inhibition of human excision DNA repair by inorganic arsenic and the co-mutagenic effect in V79 Chinese hamster cells. Mutat. Res. 1986, 172, 69-76. [CrossRef]

28. Holcomb, N.; Goswami, M.; Han, S.G.; Scott, T.; D’Orazio, J.; Orren, D.K.; Gairola, C.G.; Mellon, I. Inorganic arsenic inhibits the nucleotide excision repair pathway and reduces the expression of XPC. DNA Repair 2017, 52, 70-80. [CrossRef] 
29. Hegedûs, C.; Boros, G.; Fidrus, E.; Kis, G.N.; Antal, M.; Juhász, T.; Janka, E.A.; Jankó, L.; Paragh, G.; Emri, G.; et al. PARP1 Inhibition Augments UVB-Mediated Mitochondrial Changes-Implications for UV-Induced DNA Repair and Photocarcinogenesis. Cancers 2019, 12, 5. [CrossRef]

30. Sergey, A.; Mériam, A.; Brino, L.; Marc-Egly, J.; Larsen, A.K.; Coin, F. A small molecule screen identifies an inhibitor of DNA repair inducing the degradation of TFIIH and the chemosensitization of tumor cells to platinum. Chem. Biol. 2014, 21, 398-407.

31. Kemp, M.G.; Krishnamurthy, S.; Kent, M.N.; Schumacher, D.L.; Sharma, P.; Excoffon, K.J.; Travers, J.B. Spironolactone Depletes the XPB Protein and Inhibits DNA Damage Responses in UVB-Irradiated Human Skin. J. Investig. Dermatol. 2019, 139, 448-454. [CrossRef]

32. Ueda, M.; Matsuura, K.; Kawai, H.; Wakasugi, M.; Matsunaga, T. Spironolactone-induced XPB degradation depends on CDK7 kinase and SCF(FBXL18) E3 ligase. Genes Cells 2019, 24, 284-296. [CrossRef] [PubMed]

33. Hendrickson, A.E.W.; Menefee, M.E.; Hartmann, L.C.; Long, H.J.; Northfelt, D.W.; Reid, J.M.; Boakye-Agyeman, F.; Kayode, O.; Flatten, K.S.; Harrell, M.I.; et al. A Phase I Clinical Trial of the Poly(ADP-ribose) Polymerase Inhibitor Veliparib and Weekly Topotecan in Patients with Solid Tumors. Clin. Cancer Res. 2018, 24, 744-752. [CrossRef]

34. Kummar, S.; Ji, J.; Morgan, R.; Lenz, H.-J.; Puhalla, S.L.; Belani, C.P.; Gandara, D.R.; Allen, D.; Kiesel, B.; Beumer, J.H.; et al. A phase I study of veliparib in combination with metronomic cyclophosphamide in adults with refractory solid tumors and lymphomas. Clin. Cancer Res. 2012, 18, 1726-1734. [CrossRef] [PubMed]

35. Lowery, M.A.; Kelsen, D.P.; Capanu, M.; Smith, S.C.; Lee, J.W.; Stadler, Z.K.; Moore, M.J.; Kindler, H.L.; Golan, T.; Segal, A.; et al. Phase II trial of veliparib in patients with previously treated BRCA-mutated pancreas ductal adenocarcinoma. Eur. J. Cancer 2018, 89, 19-26. [CrossRef] [PubMed]

36. Ramalingam, S.S.; Blais, N.; Mazieres, J.; Martin Reck, C.; Jones, M.; Juhasz, E.; Urban, L.; Orlov, S.; Barlesi, F.; Kio, E.; et al. Randomized, Placebo-Controlled, Phase II Study of Veliparib in Combination with Carboplatin and Paclitaxel for Advanced/Metastatic Non-Small Cell Lung Cancer. Clin. Cancer Res. 2017, 23, 1937-1944. [CrossRef] [PubMed]

37. Struthers, A.D.; Krum, H.; Williams, G.H. A comparison of the aldosterone-blocking agents eplerenone and spironolactone. Clin. Cardiol. 2008, 31, 153-158. [CrossRef]

38. Lainscak, M.; Pelliccia, F.; Rosano, G.; Vitale, C.; Schiariti, M.; Greco, C.; Speziale, G.; Gaudio, C. Safety profile of mineralocorticoid receptor antagonists: Spironolactone and eplerenone. Int. J. Cardiol. 2015, 200, 25-29. [CrossRef]

39. Soignet, S.L.; Frankel, S.R.; Douer, D.; Tallman, M.S.; Kantarjian, H.; Calleja, E.; Stone, R.M.; Kalaycio, M.; Scheinberg, D.A.; Steinherz, P.; et al. United States multicenter study of arsenic trioxide in relapsed acute promyelocytic leukemia. J. Clin. Oncol. 2001, 19, 3852-3860. [CrossRef] [PubMed]

40. Cicconi, L.; Fenaux, P.; Kantarjian, H.; Tallman, M.; Sanz, M.A.; Lo-Coco, F. Molecular remission as a therapeutic objective in acute promyelocytic leukemia. Leukemia 2018, 32, 1671-1678. [CrossRef]

41. Gill, H.; Yim, R.; Lee, H.K.K.; Mak, V.; Lin, S.-Y.; Kho, B.; Yip, S.-F.; Lau, J.S.M.; Li, W.; Ip, H.-W.; et al. Long-term outcome of relapsed acute promyelocytic leukemia treated with oral arsenic trioxide-based reinduction and maintenance regimens: A 15-year prospective study. Cancer 2018, 124, 2316-2326. [CrossRef] [PubMed]

42. Sirerol, J.A.; Feddi, F.; Mena, S.; Rodriguez, M.L.; Sirera, P.; Aupí, M.; Pérez, S.; Asensi, M.; Ortega, A.; Estrela, J.M. Topical treatment with pterostilbene, a natural phytoalexin, effectively protects hairless mice against UVB radiation-induced skin damage and carcinogenesis. Free Radic. Biol Med. 2015, 85, 1-11. [CrossRef]

43. Fujimura, A.T.; Martinez, R.M.; Pinho-Ribeiro, F.A.; Silva, A.M.; Baracat, M.M.; Georgetti, S.R.; Verri, W.A.; Chorilli, M.; Casagrande, R. Resveratrol-Loaded Liquid-Crystalline System Inhibits UVB-Induced Skin Inflammation and Oxidative Stress in Mice. J. Nat. Prod. 2016, 79, 1329-1338. [CrossRef] [PubMed]

44. Adhami, V.M.; Afaq, F.; Ahmad, N. Suppression of ultraviolet B exposure-mediated activation of NF-kappaB in normal human keratinocytes by resveratrol. Neoplasia 2003, 5, 74-82. [CrossRef]

45. Subedi, L.; Lee, T.H.; Wahedi, H.M.; Baek, S.; Kim, S.Y. Corrigendum to "Resveratrol-Enriched Rice Attenuates UVB-ROS-Induced Skin Aging via Downregulation of Inflammatory Cascades". Oxid. Med. Cell. Longev. 2018, 2018, 6052623. [CrossRef] [PubMed]

46. Afaq, F.; Adhami, V.M.; Ahmad, N. Prevention of short-term ultraviolet B radiation-mediated damages by resveratrol in SKH-1 hairless mice. Toxicol. Appl. Pharmacol. 2003, 186, 28-37. [CrossRef]

47. Vitale, N.; Kisslinger, A.; Paladino, S.; Procaccini, C.; Matarese, G.; Pierantoni, G.M.; Mancini, F.P.; Tramontano, D. Resveratrol couples apoptosis with autophagy in UVB-irradiated HaCaT cells. PLoS ONE 2013, 8, e80728. [CrossRef]

48. Aziz, M.H.; Afaq, F.; Ahmad, N. Prevention of ultraviolet-B radiation damage by resveratrol in mouse skin is mediated via modulation in survivin. Photochem. Photobiol. 2005, 81, 25-31. [CrossRef]

49. Back, J.H.; Zhu, Y.; Calabro, A.; Queenan, C.; Kim, A.S.; Arbesman, J.; Kim, A.L. Resveratrol-mediated downregulation of Rictor attenuates autophagic process and suppresses UV-induced skin carcinogenesis. Photochem. Photobiol. 2012, 88, 1165-1172. [CrossRef]

50. Nollen, M.; Ebert, F.; Moser, J.; Mullenders, L.H.F.; Hartwig, A.; Schwerdtle, T. Impact of arsenic on nucleotide excision repair: XPC function, protein level, and gene expression. Mol. Nutr. Food Res. 2009, 53, 572-582. [CrossRef] [PubMed]

51. Boros, G. Investigation of UVB-Induced Cellular Mechanisms in Human Keratinocytes using a Novel Approach of Delivering In Vitro Synthesized mRNA Encoding Cyclobutane Pyrimidine Dimer-Specific Photolyase. Ph.D. Thesis, University of Debrecen, Debrecen, Hungary, 2015. 
52. Budden, T.; Davey, R.J.; Vilain, R.E.; Ashton, K.A.; Braye, S.G.; Beveridge, N.J.; Bowden, N.A. Repair of UVB-induced DNA damage is reduced in melanoma due to low XPC and global genome repair. Oncotarget 2016, 7, 60940-60953. [CrossRef] [PubMed]

53. Johnson, G.E. Mammalian cell HPRT gene mutation assay: Test methods. Methods Mol. Biol. 2012, 817, 55-67.

54. Greinert, R.; Boguhn, O.; Harder, D.; Breitbart, E.W.; Mitchell, D.L.; Volkmer, B. The dose dependence of cyclobutane dimer induction and repair in UVB-irradiated human keratinocytes. Photochem. Photobiol. 2000, 72, 701. [CrossRef]

55. Ikehata, H.; Mori, T.; Douki, T.; Cadet, J.; Yamamoto, M. Quantitative analysis of UV photolesions suggests that cyclobutane pyrimidine dimers produced in mouse skin by UVB are more mutagenic than those produced by UVC. Photochem. Photobiol. Sci. 2018, 17, 404-413. [CrossRef] [PubMed]

56. Qian, W.; Liu, J.; Jin, J.; Ni, W.; Xu, W. Arsenic trioxide induces not only apoptosis but also autophagic cell death in leukemia cell lines via up-regulation of Beclin-1. Leuk. Res. 2007, 31, 329-339. [CrossRef]

57. Kumar, S.; Yedjou, C.; Tchounwou, P.B. Arsenic trioxide induces oxidative stress, DNA damage, and mitochondrial pathway of apoptosis in human leukemia (HL-60) cells. J. Exp. Clin. Cancer Res. 2014, 33, 42. [CrossRef]

58. Lee, C.-H.; Yu, C.-L.; Liao, W.-T.; Kao, Y.-H.; Chai, C.-Y.; Chen, G.-S.; Yu, H.-S. Effects and interactions of low doses of arsenic and UVB on keratinocyte apoptosis. Chem. Res. Toxicol. 2004, 17, 1199-1205. [CrossRef]

59. Zhang, W.; Hanks, A.N.; Boucher, K.M.; Florell, S.R.; Allen, S.M.; Alexander, A.; Brash, D.E.; Grossman, U. UVB-induced apoptosis drives clonal expansion during skin tumor development. Carcinogenesis 2004, 26, 249-257. [CrossRef] [PubMed]

60. Eastman, A. Cell cycle checkpoints and their impact on anticancer therapeutic strategies. J. Cell. Biochem. 2004, 91, 223-231. [CrossRef]

61. Paulovich, A.G.; Toczyski, D.P.; Hartwell, L.H. When Checkpoints Fail. Cell 1997, 88, 315-321. [CrossRef]

62. Pavey, S.; Russell, T.; Gabrielli, B. G2 phase cell cycle arrest in human skin following UV irradiation. Oncogene 2001, 20 , 6103-6110. [CrossRef]

63. Tanida, I.; Ueno, T.; Kominami, E. LC3 and Autophagy. Methods Mol. Biol. 2008, 445, 77-88.

64. Ryan, K.M. p53 and autophagy in cancer: Guardian of the genome meets guardian of the proteome. Eur. J. Cancer 2011, 47, 44-50. [CrossRef]

65. Strozyk, E.; Kulms, D. The role of AKT/mTOR pathway in stress response to UV-irradiation: Implication in skin carcinogenesis by regulation of apoptosis, autophagy and senescence. Int. J. Mol. Sci. 2013, 14, 15260-15285. [CrossRef]

66. Thomas-Schoemann, A.; Batteux, F.; Mongaret, C.; Nicco, C.; Chéreau, C.; Annereau, M.; Dauphin, A.; Goldwasser, F.; Weill, B.; Lemare, F.; et al. Arsenic trioxide exerts antitumor activity through regulatory $\mathrm{T}$ cell depletion mediated by oxidative stress in a murine model of colon cancer. J. Immunol. 2012, 189, 5171-5177. [CrossRef]

67. Carone, L.; Oxberry, S.G.; Twycross, R.; Charlesworth, S.; Mihalyo, M.; Wilcock, A. Spironolactone. J. Pain Symptom Manag. 2017, 53, 288-292. [CrossRef]

68. Li, S.; Topatana, W.; Juengpanich, S.; Cao, J.; Hu, J.; Zhang, B.; Ma, D.; Cai, X.; Chen, M. Development of synthetic lethality in cancer: Molecular and cellular classification. Signal Transduct. Target Ther. 2020, 5, 1-14. [CrossRef] [PubMed]

69. Helleday, T. The underlying mechanism for the PARP and BRCA synthetic lethality: Clearing up the misunderstandings. Mol. Oncol. 2011, 5, 387-393. [CrossRef] [PubMed]

70. Lord, C.J.; Tutt, A.N.; Ashworth, A. Synthetic Lethality and Cancer Therapy: Lessons Learned from the Development of PARP Inhibitors. Annu. Rev. Med. 2015, 66, 455-470. [CrossRef]

71. Chaudhuri, A.R.; Nussenzweig, A.R.C.A. The multifaceted roles of PARP1 in DNA repair and chromatin remodelling. Nat. Rev. Mol. Cell Biol. 2017, 18, 610-621. [CrossRef] [PubMed]

72. Pines, A.; Vrouwe, M.G.; Marteijn, J.A.; Typas, D.; Luijsterburg, M.S.; Cansoy, M.; Mullenders, L. PARP1 promotes nucleotide excision repair through DDB2 stabilization and recruitment of ALC1. J. Cell Biol. 2012, 199, 235-249. [CrossRef]

73. Robu, M.; Shah, R.G.; Purohit, N.K.; Zhou, P.; Naegeli, H.; Shah, G.M. Poly(ADP-ribose) polymerase 1 escorts XPC to UV-induced DNA lesions during nucleotide excision repair. Proc. Natl. Acad. Sci. USA 2017, 114, E6847-E6856. [CrossRef]

74. Thorslund, T.; Von Kobbe, C.; Harrigan, J.A.; Indig, F.E.; Christiansen, M.; Stevnsner, T.; Bohr, V.A. Cooperation of the Cockayne syndrome group B protein and poly(ADP-ribose) polymerase 1 in the response to oxidative stress. Mol. Cell. Biol. 2005, 25, 7625-7636. [CrossRef] [PubMed]

75. Chiu, H.; Ho, Y.-S.; Wang, Y.-J. Arsenic trioxide induces autophagy and apoptosis in human glioma cells in vitro and in vivo through downregulation of survivin. J. Mol. Med. 2011, 89, 927-941. [CrossRef] [PubMed]

76. Liu, Q.; Gheorghiu, L.; Drumm, M.; Clayman, R.; Eidelman, A.; Wszolek, M.F.; Olumi, A.; Feldman, A.; Wang, M.; Marcar, L.; et al. PARP-1 inhibition with or without ionizing radiation confers reactive oxygen species-mediated cytotoxicity preferentially to cancer cells with mutant TP53. Oncogene 2018, 37, 2793-2805. [CrossRef] [PubMed]

77. Vance, S.M.; Liu, E.; Zhao, L.; Parsels, J.D.; Parsels, L.A.; Brown, J.L.; Maybaum, J.; Lawrence, T.S.; Morgan, M.A. Selective radiosensitization of p53 mutant pancreatic cancer cells by combined inhibition of Chk1 and PARP1. Cell Cycle 2011, 10, 4321-4329. [CrossRef]

78. Valenzuela, M.T.; Guerrero, R.; Nuñez, M.I.; De Almodóvar, J.M.R.; Sarker, M.; De Murcia, G.; Oliver, F.J. PARP-1 modifies the effectiveness of p53-mediated DNA damage response. Oncogene 2002, 21, 1108-1116. [CrossRef]

79. Kubota, E.; Williamson, C.T.; Ye, R.; Elegbede, A.; Peterson, L.; Lees-Miller, S.P.; Bebb, D.G. Low ATM protein expression and depletion of p53 correlates with olaparib sensitivity in gastric cancer cell lines. Cell Cycle 2014, 13, 2129-2137. [CrossRef] 
80. Kanai, M.; Hanashiro, K.; Kim, S.-H.; Hanai, S.; Boulares, A.H.; Miwa, M.; Fukasawa, K. Inhibition of Crm1-p53 interaction and nuclear export of p53 by poly(ADP-ribosyl)ation. Nat. Cell Biol. 2007, 9, 1175-1183. [CrossRef]

81. Lorin, S.; Hamaï, A.; Mehrpour, M.; Codogno, P. Autophagy regulation and its role in cancer. Semin. Cancer Biol. 2013, 23, 361-379. [CrossRef]

82. Boros, G.; Miko, E.; Muramatsu, H.; Weissman, D.; Emri, E.; Rózsa, D.; Nagy, G.; Juhász, A.; Juhász, I.; Van Der Horst, G.; et al. Transfection of pseudouridine-modified mRNA encoding CPD-photolyase leads to repair of DNA damage in human keratinocytes: A new approach with future therapeutic potential. J. Photochem. Photobiol. B Biol. 2013, 129, 93-99. [CrossRef] [PubMed] 